\title{
Effect of Caffeinated Beverages Intake on Premenstrual Syndrome among Nursing Students
}

\author{
Sherehan R. A.1, Galal A. E.2 ,Soad A. R.3 and Eman M. A.3 \\ (1) Kafr Elshikh ophthalmology center Specialist, Egypt. \\ (2) Obstetrics \&gynecology ,Faculty of Medicine ,Benha University, Egypt. \\ (3) Obstetrics \&gynecology ,Faculty of Medicine ,Benha University, Egypt.
}

\begin{abstract}
Premenstrual syndrome (PMS) is a condition with distressing physical, behavioral and psychological symptoms in the absence of organic or underlying psychiatric disease.A potentially important dietary factor in PMS is caffeine.It is estimated that approximately $80 \%$ of the world's population uses caffeine on a daily basis mainly in the form of coffee, tea, sodas and chocolate. So, Aim of this study: was to study the effect of caffeinated beverages intake on premenstrual syndrome among nursing students. Design: Correlative study design was utilized to achieve the aim of the study.. Setting: The present study was conducted at Faculty of Nursing in Benha University Sample::Purposive sample. Tools of data collection: Three tools were used: tool (1) interviewing questionnaire including five parts, tool (2):-Self Administered Questionnaire (Follow up sheet) consisted of five parts. tool (3):- Written leaflets. Results: Showed that there was no statistically significant difference regarding socio-demographic characteristics between both groups. No statistically significant difference was reported regarding consumption of any type of caffeinated beverages ( $>0.05$ ). Total caffeinated beverage consumption showed highly statistically significant decrease among students with moderate and severe PMS. Positive correlation between the reduction of caffeinated beverages intake and decrease in PMS severity and duration along all follow - up cycles. Conclusion: The study concluded that,caffeine consumption was strongly positively linked to both the severity and duration of PMS. Recommendations: The study recommended that counseling adolescent females to reduce caffeine consumption from diet especially the week preceding menstruation and encourage young females to use menstrual diary monthly. In addition, establishing education program for all female students for increasing their knowledge about PMS.
\end{abstract}

Key words: Premenstrual syndrome, Caffeinated Beverages and Nursing Students.

\section{Introduction}

Premenstrual syndrome is a collection of physical, psychological, and emotional symptoms related to a woman's menstrual cycle ( Akram et al., 2011). In addition 
symptoms usually occurs in women at late 20 to early 40 years. Symptoms usually begin when a woman is in her mid-twenties. Naturally, PMS and other menstrual problems end at menopause when a woman stops having menstrual periods (Pinkerton \&Guico, 2010).PMS can affect menstruating women of any age and the effect is different for each woman..Barclift, 2010). The syndrome is estimated to affect up to $80 \%$ of premenopausal women with varying levels of impairment. Approximately 5-6\% of women suffer from the most severe form of PMS called premenstrual dysphoric disorder (PMDD). PMDD is a debilitating and primarily affective disorder, often results in women seeking medical treatment and is associated with the most impairment on women's quality of life. It can affect work, school and academic performance, and lead to problems, conflicts in interpersonal relationships (Biggs \& Demuth, 2011).PMS appears in the form of psychological symptoms which include (mood swings, irritability, depression and anxiety) physical symptoms which include (breast tenderness, abdominal cramps, bloating, swelling, acne, backache, increased appetite, sleep problem and headaches) and behavioral symptoms including reduced cognitive ability, and increased accidents (Brohi et al., 2011).The cause of PMS is unknown, theories include hormonal imbalances such as ovarian steroid interaction, dysfunctions of neurotransmitters (such as serotonin), low level of betaendorphins, fluctuations in levels of circulating estrogen and progesterone, abnormal production of prostaglandins as well as excess aldosterone or anti diuretics hormone can cause transitory fluid retention and environmental factors such as nutrition and pollution (Biggs \& Demuth, 2011) .

Caffeine is the most commonly consumed psychoactive or central nervous system stimulant in the world. It works to temporarily block drowsiness and restore alertness. It is found naturally in many plantbased foods, such as coffee, tea, cocoa, and kola nuts. It is also commonly added to colas, soft-drinks, energy drinks, and other products (Meier, 2013).It is estimated that approximately $80 \%$ of the world's population uses caffeine on a daily basis mainly in the form of coffee, tea, sodas and chocolate.(International Food Information Council Foundation, 2015).Chemically, caffeine is known as 1,3,7-trimethylxanthine. After absorption caffeine is distributed throughout body water and reaches peak plasma concentrations between 15-120 minutes with a mean half-life of five hours (Falls, 2013).

A potentially important dietary factor in PMS is caffeine. some researchers reported that unhealthy habits increase the severity of PMS and one of the unhealthy habits is intake of caffeinated beverages and improvement in premenstrual symptoms following reduction in caffeine intake (Jiang, 2014).

\section{Aim of The Study}

This study aimed to study the effect of caffeinated beverages intake on premenstrual syndrome among nursing students.

\section{Research questions}

Is a relationship between caffeinated beverages intakes and severity of premenstrual syndrome and duration?

\section{Subjects And Method}

Design: Correlative study design was utilized to achieve the aim of the study.

\section{Settings}

This study was conducted at Faculty of Nursing in Benha University.

Study Sample: (Purposive sample). 
A sample of 150 nursing students were chosen based on the following sample size calculation using the equation considering the percentage of PMS, confidence level and margin of error (Brink D, 2010)

\section{Sample size equation}

$$
\begin{aligned}
& \mathbf{N}=\left(\mathbf{Z}^{2 *} \mathbf{P} * \mathbf{Q}\right) /\left(\mathbf{D}^{2}\right) \\
& \mathbf{Z}=1.96 \\
& \mathbf{P}=\text { No of affected pop } \\
& \mathbf{Q}=1-\mathrm{p}= \\
& \mathbf{E r r o r}=.05 \% \\
& \mathbf{P}=14 \& 10 \quad \mathrm{Q}=86 \& 90 \\
& \mathbf{N}=185 \& 138
\end{aligned}
$$

So, $\mathrm{n}=(185+138) / 2=323 / 2=161.5$ $=162$. With1 2 person's rejection, it equals 150

\section{Selection criteria:}

The researcher recruited the whole study population (all eligible nursing students from different academic years according to following inclusion criteria:-

1-Have regular menstruation within the last 6 months prior to the study.2-Have moderate and severe PMS during the last 6 months prior to the study.3- Not using any medication or herbal formulations during PMS period to overcome PMS discomforts.4Consuming caffeinated beverages intake during the week just preceding menstruation. 5- Not having any chronic diseases or regular use of medications.6-Un married, Thenselected students who met the inclusion criteria were randomly divided into 2 equal groups:

Group (1) study group $=75$ students Group (2) control group $=75$ students

\section{Tools of data collection}

Data were collected through the following tools:-

Tool (1):(Interviewing questionnaire)

It was designed by the researcher after reviewing related literatures, it composed of five parts:-

Part (1): student nurse's general characteristics as (age, academic year, residence, family income, etc.....)

Part (2): past medical history included medical diseases and hereditary diseases.

Part (3): Menstrual history included (age of menarche, regularity of menstruation, interval of menstruation, duration of menstruation, etc...)

Part(4):Premenstrual

period included(physical and psychological symptoms in the previous six months at premenstrual period adapted from Moos $\boldsymbol{R}$., (1968)named Menstrual Distress Questionnaire (MDQ), Moos et al., (1968) .

Part (5): Caffeinated beverages intake in previous six months included (daily amount intake from caffeinated beverages and its type.

Tool(II):(Follow up sheet) It was developed by researcher to collect necessary data it includes the following parts: data.

Part (1): Demographic characteristics

Part (2) Standardized Premenstrual Diary. The diary is adopted from Dickerson et al., (2003) 
Part (3): History of menstrual period.

Part (4): premenstrual period.

Part (5): Types and amount of daily caffeinated beverages intake during the week before menstruation

Tool III:Written instruction leaflets. Two simple leaflets were designed by researcher for instructing study sample about PMS, reduce caffeinated beverages intake and guidelines to be followed regarding this point. This leaflet was distributed on the two groups but before follow up phase to study group and to control group after end of follow up phase.

\section{A written permission}

An official permission was obtained from the dean of Benha Nursing Faculty examining the purpose of the study and methods of data collection.

\section{Validity and reliability:}

The validity of the tool was tested by jury of 3 experts in obstetrics and gynecology field who reviewed the tool for content validity. Also, they were asked to judge the items for completeness and clarity and suggestions were considered. The reliability of the tool was done.

\section{Pilot Study}

A pilot study was conducted on $10 \%$ of the sample (15) students to assess the clarity of the tools used for data collection and to estimate the time needed for data collection. No modifications occurred so the sample of pilot study was included in the main study sample.

\section{Ethical considerations}

The researcher explained the aim of the study to the students. They were informed that the study is harmless. The researcher secured that all of the gathered data are confidential and are used for the research purpose only. The students were informed that they are optionally allowed either to participate or not in the study and they have the right to withdraw at any time. An oral consent was taken from the students.

\section{Data collection procedure:}

The study was carried out from the beginning of February 2016 to the end of June 2016 covered 5 months. It was done on three days per week and five hours per day. The current study was carried out through following phases:

\section{A) Recruitment phase:}

The researcher interviewed with students to conduct eligibility of participants based on the inclusion criteria. This step was repeated until the sample size was completed. Instructions were given to students to fill structured questionnaire sheet. The researcher clarified any question to students if needed then collected the questionnaire sheets and ensured that all questions were answered, time taken to complete this sheet 15 minutes.

\section{B) Implementation phase:}

Selected students who met the inclusion criteria were randomly divided into 2 equal groups: group (1) control group $=75$ students and group (2) study group $=75$ students. The researcher planned three sessions (one hour during the day with 25 students from study group only in each session) for giving instructions regarding filling selfadministered questionnaire sheet (follow up sheet) or the dairies alone at home and instructed them to limit caffeinated beverages intake during the week before menstruation \&distributed simple leaflets. The researcher planned another three sessions (one hour during the day with 25 students from control group only in each session) and gave same instruction regarding filling self-administered 
questionnaire (follow up sheet) but this group instructed to keep regular daily caffeinated beverage intake. The researcher instructed students in both groups to fill diary

Expected $=\frac{\text { col.total } x \text { rowtotal }}{\text { Grand total }}$

daily at home on the same time for a complete month for 3 months. Then, took an appointment from studied students to collect follow up sheets every month.

\section{C) Follow up phase:}

It lasted for 3 months to follow up the severity of PMS symptoms in study group (after limiting caffeinated beverage) and for control group who keep free regular caffeinated beverages intake without reduction. The researcher distributed simple leaflet to control group after the end of follow up phase.

\section{Statistical design}

Data were coded and transformed into specially designed form to be suitable for computer data entry process

The clinical data were recorded on a report form. These data were tabulated and analyzed using the computer program SPSS (Statistical package for social science) version 20 to obtain:

\section{*Descriptive data}

Descriptive statistics were calculated for the data in the form of frequency and distribution for qualitative data.

\section{*Analytical statistics}

In the statistical comparison between the different groups, the significance of difference was tested using the following tests: -

Inter-group comparison of categorical data was performed by using chi square test $\left(X^{2}\right.$-value) and fisher exact test (FET).

$$
x^{2}=\frac{\sum(\text { observed }-\exp \text { ected })^{2}}{\text { Expected }}
$$

A $\mathrm{P}$ value $<0.05$ was considered statistically significant while $>0.05$ statistically insignificant $\mathrm{P}$ value $<0.01$ was considered highly significant in all analyses.

\section{Study Limitations}

* Many students were busy and had lectures during data collections.

* Many students showed complete rejection to give the researcher telephone number and email 
Results

Table (1): Demographic characteristics of studied groups $(n=150)$.

\begin{tabular}{|c|c|c|c|c|c|c|}
\hline \multirow[t]{2}{*}{ Parameter } & \multicolumn{2}{|c|}{$\begin{array}{l}\text { Study group } \\
\quad(\text { no }=75)\end{array}$} & \multicolumn{2}{|c|}{$\begin{array}{l}\text { Control group } \\
\quad(n o=75)\end{array}$} & \multirow{2}{*}{$\begin{array}{l}\text { Chi } \\
\text { Square } \\
\text { Test }\end{array}$} & \multirow[t]{2}{*}{$P$ valuc } \\
\hline & No & $\%$ & No & $\%$ & & \\
\hline $\begin{array}{l}\text { Age (years) } \\
18-20 \\
21-23 \\
24-26 \\
\text { Mean } \pm \text { SD } \\
\mathbf{2 2 . 4 6} \pm \mathbf{1 . 7}\end{array}$ & $\begin{array}{c}14 \\
43 \\
18 \\
\mathbf{2 2 . 1 7} \pm \mathbf{3 . 1}\end{array}$ & $\begin{array}{l}18.7 \\
57.3 \\
24.0\end{array}$ & $\begin{array}{c}9 \\
49 \\
17 \\
\mathbf{2 3 . 3 1} \pm \mathbf{2 . 6}\end{array}$ & $\begin{array}{l}12.0 \\
65.3 \\
22.7\end{array}$ & 1.51 & $>0.05$ \\
\hline $\begin{array}{l}\text { Academic year } \\
1 \text { st } \\
\text { 2nd } \\
\text { 3rd } \\
4^{\text {th }} \\
\end{array}$ & $\begin{array}{c}3 \\
14 \\
25 \\
33 \\
\end{array}$ & $\begin{array}{c}4.0 \\
18.7 \\
33.3 \\
44.0 \\
\end{array}$ & $\begin{array}{c}5 \\
15 \\
24 \\
31 \\
\end{array}$ & $\begin{array}{c}6.7 \\
20.0 \\
32.0 \\
41.3 \\
\end{array}$ & $\begin{array}{l}\wedge 0.655 \\
\text { FET }\end{array}$ & $>0.05$ \\
\hline $\begin{array}{l}\text { Residence } \\
\text { Rural } \\
\text { Urban }\end{array}$ & $\begin{array}{l}48 \\
27\end{array}$ & $\begin{array}{l}64.0 \\
36.0\end{array}$ & $\begin{array}{l}42 \\
33\end{array}$ & $\begin{array}{l}56.0 \\
44.0\end{array}$ & 1.0 & $>0.05$ \\
\hline $\begin{array}{l}\text { Mother education } \\
\text { Illiterate } \\
\text { Primary } \\
\text { Secondary } \\
\text { University }\end{array}$ & $\begin{array}{c}41 \\
9 \\
20 \\
5 \\
\end{array}$ & $\begin{array}{c}54.6 \\
12 \\
26.6 \\
6.6\end{array}$ & $\begin{array}{c}36 \\
10 \\
26 \\
3 \\
\end{array}$ & $\begin{array}{c}48 \\
13.3 \\
34.6 \\
4 \\
\end{array}$ & $\begin{array}{l}\wedge 1.66 \\
\text { FET }\end{array}$ & $>0.05$ \\
\hline $\begin{array}{l}\text { Mother occupation } \\
\text { Work } \\
\text { Not work }\end{array}$ & $\begin{array}{l}20 \\
55\end{array}$ & $\begin{array}{l}26.7 \\
73.3\end{array}$ & $\begin{array}{l}27 \\
48\end{array}$ & $\begin{array}{l}36.0 \\
64.0\end{array}$ & 1.52 & $>0.05$ \\
\hline $\begin{array}{l}\text { Family income } \\
\text { Low income } \\
\text { Moderate income } \\
\text { High income }\end{array}$ & $\begin{array}{l}55 \\
15 \\
5\end{array}$ & $\begin{array}{l}73.3 \\
20.0 \\
6.6\end{array}$ & $\begin{array}{l}49 \\
23 \\
3\end{array}$ & $\begin{array}{l}65.3 \\
30.6 \\
4.0\end{array}$ & $\wedge 2.53$ & $>0.05$ \\
\hline
\end{tabular}

\section{$\mathbf{P}>\mathbf{0 . 0 5}=$ No significant difference}

Table (1): shows that $57.3 \%$ and $65.3 \%$ of study and control samples were $21-23$ years old Mean \pm SD (22.46 \pm 1.7 years). $44.0 \%$ and $41.3 \%$ of study and control groups from 4 th academic year respectively. $64 \%$ and $56 \%$ in study and control groups live in rural area, $54.6 \%$ and $48 \%$ had 
illiterate mother, $73.3 \%$ and $65.3 \%$ have low income, only $26.7 \%$ and $36 \%$ have working mothers. There is no statistically significant difference between two groups regarding age, academic year, residence, mother education, mother occupation $(\mathrm{P}>0.05)$

Table (2): Distribution of study sample according to menstrual history $(n=150)$.

\begin{tabular}{|c|c|c|c|c|c|c|}
\hline \multirow{2}{*}{ Parameter } & \multicolumn{2}{|c|}{$\begin{array}{l}\text { Study group } \\
\qquad(\mathbf{n}=\mathbf{7 5})\end{array}$} & \multicolumn{2}{|c|}{$\begin{array}{l}\text { Control group } \\
\qquad(\mathbf{n}=75)\end{array}$} & \multirow{2}{*}{$\begin{array}{l}\text { FET } \\
\text { Test }\end{array}$} & \multirow{2}{*}{$P$ value } \\
\hline & No & $\%$ & No & $\%$ & & \\
\hline $\begin{array}{l}\text { Age at menarche(years) } \\
\text { 10-12years } \\
12-14 \text { years } \\
14-16 \text { years } \\
\text { Mean } \pm \text { SD } \\
\mathbf{1 2 . 0} \pm \mathbf{1 . 5 5}\end{array}$ & $\begin{array}{c}28 \\
46 \\
1 \\
\mathbf{1 2 . 3 2} \pm \mathbf{1 0 4}\end{array}$ & $\begin{array}{c}37.3 \\
61.3 \\
1.3\end{array}$ & $\begin{array}{c}20 \\
55 \\
0 \\
\mathbf{1 1 . 6 7} \pm \mathbf{1 . 7}\end{array}$ & $\begin{array}{c}26.7 \\
73.3 \\
0.0\end{array}$ & $\wedge 3.05$ & $>0.05$ \\
\hline $\begin{array}{l}\text { Regularity of menstruation } \\
\text { Regular }\end{array}$ & 75 & 100 & 75 & 100 & - & - \\
\hline $\begin{array}{l}\text { Duration of menstruation } \\
\text { Less than } 3 \text { day } \\
\text { From } 3-7 \text { day } \\
\text { More than } 7 \text { day }\end{array}$ & $\begin{array}{c}0 \\
75 \\
0 \\
\end{array}$ & $\begin{array}{l}0.0 \\
100 \\
0.0\end{array}$ & $\begin{array}{c}0 \\
75 \\
0 \\
\end{array}$ & $\begin{array}{c}0.0 \\
100 \\
0.0\end{array}$ & - & - \\
\hline $\begin{array}{l}\text { Menstrual interval } \\
\text { From } 21-35 \text { day }\end{array}$ & 75 & 100 & 75 & 100 & - & - \\
\hline $\begin{array}{l}\text { Daily pads } \\
\text { 1-2/days } \\
\text { 3-4/days } \\
>5 / \text { days }\end{array}$ & $\begin{array}{c}31 \\
41 \\
2\end{array}$ & $\begin{array}{c}41.9 \\
55.4 \\
2.7\end{array}$ & $\begin{array}{c}33 \\
35 \\
7\end{array}$ & $\begin{array}{c}44.0 \\
46.7 \\
9.3\end{array}$ & $\wedge 3.2$ & $>0.05$ \\
\hline $\begin{array}{l}\text { Amount of blood loss } \\
\text { Little } \\
\text { Moderate } \\
\text { Heavy } \\
\end{array}$ & $\begin{array}{c}31 \\
41 \\
2\end{array}$ & $\begin{array}{c}41.9 \\
55.4 \\
2.7\end{array}$ & $\begin{array}{c}33 \\
35 \\
7\end{array}$ & $\begin{array}{c}44.0 \\
46.7 \\
9.3\end{array}$ & $\wedge 3.2$ & $>0.05$ \\
\hline $\begin{array}{l}\text { Blood clots } \\
\text { Yes } \\
\text { No }\end{array}$ & $\begin{array}{c}7 \\
68 \\
\end{array}$ & $\begin{array}{c}9.3 \\
90.7\end{array}$ & $\begin{array}{c}1 \\
74 \\
\end{array}$ & $\begin{array}{c}1.3 \\
98.7\end{array}$ & $\wedge 3.3$ & $>0.05$ \\
\hline
\end{tabular}

\section{$\mathbf{P}>0.05=$ No significant difference}

Table (2): reveals that $61.3 \%$ and $73.3 \%$ had menarche between $12-14$ years for study and control groups respectively with mean age of menarche $12.0 \pm 1.55$. All studied sample had regular menstrual cycle $(100 \%)$ with menstrual duration of 3-7 days (100\%) and with menstrual interval of 
21-35 day (100\%). 55.4\% and 46.7\% of both group respectively had moderate amount of blood loss with changing daily pads from 3-4 pads /day, 9.3\% and 1.3\% of both groups respectively have blood clots during menses and no statistically significance difference between two groups regarding age of menarche, regularity of menstruation, duration, interval, daily pads, amount of blood loss and blood clots.

Table(3):Distribution of the studied samples according to Premenstrual Symptoms during the last 6 months (Recruitment phase) $(n=150)$.

\begin{tabular}{|c|c|c|c|c|c|c|}
\hline \multirow{2}{*}{ Parameter } & \multicolumn{2}{|c|}{$\begin{array}{l}\text { Study group } \\
(\text { no =75) }\end{array}$} & \multicolumn{2}{|c|}{$\begin{array}{l}\text { Control group } \\
(n o=75)\end{array}$} & \multirow{2}{*}{$\begin{array}{l}\text { Chi- } \\
\text { Square } \\
\text { Test }\end{array}$} & \multirow{2}{*}{$P$ value } \\
\hline & No & $\%$ & No & $\%$ & & \\
\hline $\begin{array}{l}\text { Psychological symptoms } \\
\text { Yes } \\
\text { No }\end{array}$ & $\begin{array}{l}54 \\
21\end{array}$ & $\begin{array}{l}72.0 \\
28.0\end{array}$ & $\begin{array}{l}56 \\
19\end{array}$ & $\begin{array}{l}74.7 \\
25.3\end{array}$ & 0.14 & $>0.05$ \\
\hline $\begin{array}{l}\text { Behavioral symptoms } \\
\text { Yes } \\
\text { No }\end{array}$ & $\begin{array}{l}35 \\
40\end{array}$ & $\begin{array}{l}46.7 \\
53.3\end{array}$ & $\begin{array}{l}37 \\
38\end{array}$ & $\begin{array}{l}49.3 \\
50.7\end{array}$ & 0.11 & $>0.05$ \\
\hline $\begin{array}{l}\text { Pain symptoms } \\
\text { Yes } \\
\text { No }\end{array}$ & $\begin{array}{l}55 \\
20\end{array}$ & $\begin{array}{l}73.3 \\
26.7\end{array}$ & $\begin{array}{l}62 \\
13 \\
\end{array}$ & $\begin{array}{l}82.7 \\
17.3\end{array}$ & 1.9 & $>0.05$ \\
\hline $\begin{array}{l}\text { Bloatedness } \\
\text { Yes } \\
\text { No }\end{array}$ & $\begin{array}{l}52 \\
23\end{array}$ & $\begin{array}{l}69.3 \\
30.7\end{array}$ & $\begin{array}{l}53 \\
22\end{array}$ & $\begin{array}{l}70.7 \\
29.3\end{array}$ & 0.03 & $>0.05$ \\
\hline $\begin{array}{l}\text { Appetite symptoms } \\
\text { Yes } \\
\text { No }\end{array}$ & $\begin{array}{l}38 \\
37\end{array}$ & $\begin{array}{l}50.7 \\
49.3\end{array}$ & $\begin{array}{l}42 \\
33\end{array}$ & $\begin{array}{l}56.0 \\
44.0\end{array}$ & 0.43 & $>0.05$ \\
\hline
\end{tabular}

$\mathrm{P}>0.05=$ No significant difference

Table (3): shows no statistically significant difference between study and control samples regarding PMS symptoms. $73.3 \%$ and $82.7 \%$ respectively of samples have pain symptoms, $(72.0 \%$ and $74.7 \%$ ) have psychological symptoms and $(69.3 \%$ and $70.7 \%)$ have bloatedness symptoms and $(50.7 \%$ and $56.0 \%)$ have appetite symptoms and $(46.7 \%$ and $49.3 \%)$ have behavioral symptoms. 


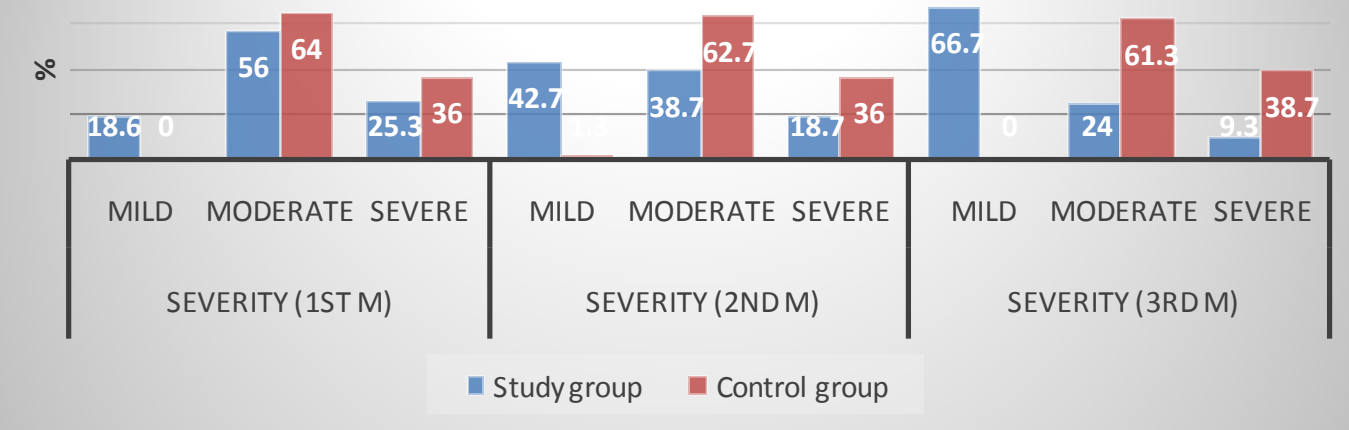

Figure (1): premenstrual syndrome severity for study and control group along follow up phase $(\mathbf{n}=150)$

Figure (1): shows premenstrual syndrome severity for study and control group through 3 months of follow up. PMS severity was significantly decrease from month to month in study group. During the $1^{\text {st }}$ month of follow up (25.3\%) were experiencing severe PMS, $(56.0 \%)$ moderate PMS and $(18.6 \%)$ mild PMS at study group compared to (36 \%) severe PMS, (64\%) moderate PMS and $(0.0 \%)$ mild at control group. In study group (18.7\%) were experiencing severe PMS, $(38.7 \%)$ moderate and $42.7 \%$ mild PMS during $2^{\text {nd }}$ month of follow up compared to $36.0 \%$ severe PMS, 62.7 moderate and $1.3 \%$ mild PMS at control group and during the last month at study group $66.7 \%$ were experiencing mild PMS, $24.0 \%$ moderate and only $9.3 \%$ severe PMS compared to $0.0 \%$ mild PMS, 61.35 moderate PMS and 38.7\% severe PMS at control group.

Table (4): Distribution of studied samples according to duration of PMS (follow up) $(n=150)$

\begin{tabular}{|c|c|c|c|c|c|c|}
\hline \multirow{2}{*}{ Parameter } & \multicolumn{2}{|c|}{$\begin{array}{l}\text { Study group } \\
(\text { no=75) }\end{array}$} & \multicolumn{2}{|c|}{$\begin{array}{l}\text { Control group } \\
(\text { no }=75)\end{array}$} & \multirow{2}{*}{ FET Test } & \multirow{2}{*}{$P$ value } \\
\hline & No & $\%$ & No & $\%$ & & \\
\hline $\begin{array}{l}\text { Follow up (cycle 1) } \\
\text { Yes } \\
\text { No }\end{array}$ & $\begin{array}{l}53 \\
22\end{array}$ & $\begin{array}{l}70.7 \\
29.3\end{array}$ & $\begin{array}{c}0 \\
75\end{array}$ & $\begin{array}{c}0.0 \\
100\end{array}$ & 81.96 & $0.001 * *$ \\
\hline $\begin{array}{l}\text { Follow up (cycle 2) } \\
\text { Yes } \\
\text { No }\end{array}$ & $\begin{array}{l}59 \\
16 \\
\end{array}$ & $\begin{array}{l}78.7 \\
21.3 \\
\end{array}$ & $\begin{array}{c}0 \\
75\end{array}$ & $\begin{array}{l}0.0 \\
100\end{array}$ & 97.3 & $0.001 * *$ \\
\hline $\begin{array}{l}\text { Follow up (cycle 3) } \\
\text { Yes } \\
\text { No }\end{array}$ & $\begin{array}{c}66 \\
9 \\
\end{array}$ & $\begin{array}{l}88.0 \\
12.0\end{array}$ & $\begin{array}{c}0 \\
75\end{array}$ & $\begin{array}{l}0.0 \\
100\end{array}$ & 117.9 & $0.001 * *$ \\
\hline
\end{tabular}

** highly statistically significant at $\mathbf{p}<0.001$

Table (4): shows a highly statistically significant difference between study and control groups with decrease in PMS duration through all follow up cycles. In study group (70.7\%) 
experienced a decrease in duration of PMS during $1^{\text {st }}$ cycle. During the $2^{\text {nd }}$ cycle $(78.7 \%)$ of the study group experienced such decrease. During $3^{\text {rd }}$ cycle the percentage of participants was $(88.0 \%)$ in study group meanwhile the percentage of participants in control group experienced a decrease in PMS duration were stable through all follow up cycle $(0 \%)$. Severity of PMS decrease from month to month after decreasing caffeinated beverages intake.

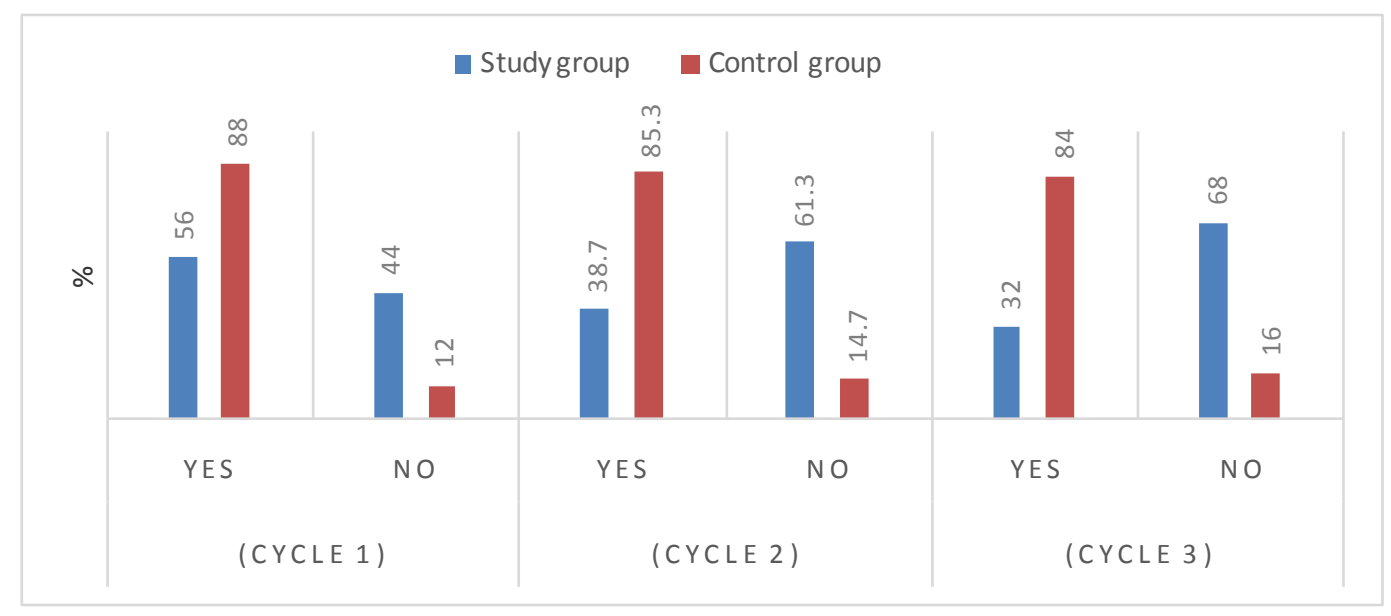

Figure (2): Interference of premenstrual syndrome with daily activities for study and control group along follow up phase $(n=150)$.

Figure (2): shows the interference of premenstrual syndrome with daily activities for study and control group along follow up phase. The figure showed that the interference of premenstrual syndrome with daily activities was significantly decrease from month to month in study group. During the $1^{\text {st }}, 2^{\text {nd }}$ and $3^{\text {rd }}$ month of follow up $(56.0 \%, 38.7 \%$ and $32.0 \%)$ of study group respectively were experiencing of that interference, compared to $(88.0 \%, 85.3 \%$ and $84.0 \%$ )at control group.

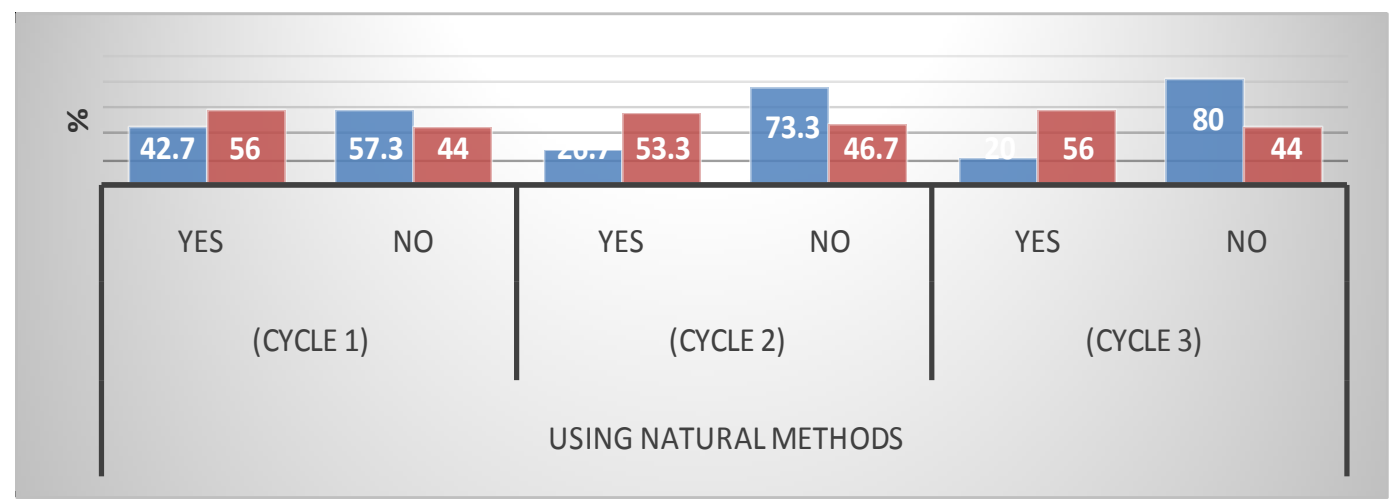

Figure (4): Using of lifestyle methods to overcome PMS for study and control group along follow up phase 
Figure (3):shows using of lifestyle methods to overcome PMS for study and control group along follow up phase. The figure appears that the using of lifestyle methods to overcome PMS was significantly decrease from month to month in study group. During the $1^{\text {st }}, 2^{\text {nd }}$ and $3^{\text {rd }}$ month of follow up $(42.7 \%, 26.7 \%$ and $20.0 \%)$ of study group respectively were using natural methods to overcome PMS meanwhile $(56.0 \%, 53.3 \%$ and $56.0 \%$ )at control group were using lifestyle methods to overcome PMS during $1^{\text {st }}, 2^{\text {nd }}$ and $3^{\text {rd }}$ month of follow up respectively.

Table (5) Correlation between reducing caffeinated beverage intake and premenstrual syndrome severity along follow up cycle $(n=150)$

\begin{tabular}{|l|c|c|}
\hline \multirow{2}{*}{ Reducing caffeinated beverages intake } & \multicolumn{2}{|c|}{ Severity } \\
& $\mathbf{r}$ & P value \\
\cline { 2 - 3 } & 0.134 & 0.147 \\
\hline Follow up cycle 1 & 0.377 & $0.001^{* *}$ \\
\hline Follow up cycle 2 & 0.307 & $0.001^{* *}$ \\
\hline
\end{tabular}

** highly statistically significant at $\mathbf{p}<0.001$

Table (5): The table shows that a positive correlation between the reduction of caffeinated beverages intake and decrease in PMS severity at all follow -up cycles $(p<0.001)$.

\section{Discussion}

The problem of premenstrual syndrome is prevalent among women's in childbearing period; measures to reduce this problem are important and beneficial(Bekhatro et al., 2010).Some researchers theorized that un healthy habits increase the severity of PMS and one of the unhealthy habits is the intake of caffeinated beverages and improvement in premenstrual symptoms following reduction in caffeine intake. Regarding socio-demographic characteristics of the studied sample, the present study showed no statistically significant difference between study and control groups. The age of nearly two thirds of studied samples ranged between $(21-23$ years) and mean age of the studied sample was $22.46 \pm 1.7$ and all studied sample were unmarried. This result agrees with Navdeepkuar,(2010)who mentioned that the mean age of studied sample was 20.8226 +1.05189 years old and majority of sample aged 21- 30 years.more than two thirds in study group and more than one half of control group have PMS and live in rural area but the association was not statistically significant, this finding agreed with Asmare et al .,(2015). The current study found that about half of samples had illiterate mothers and more than two thirds have un employed mothers but the association was not statistically significant. Regarding age of menarche, the present study indicated that more than two thirds of participants had menarche at 12-14 years with mean age $12.0 \pm 1.55$. This result was consistent with study conducted by $\boldsymbol{A b d}$ El-Hamid et al .,(2013) and found that majority of the studied sample had menarche at $13 \pm .8$ years . Additionally, Bayan et al., (2012) foundthat the mean age of menarche study of sample was $13.3 \pm 1.4$ years the results also agree with Jenabi , (2013)who found that the girls had their menarche at the age of $11 \leq 13$ years. studied samples had regular period, with normal menstrual interval (21-35 days), and with normal menstrual duration (3-7 days). This result agrees with Diaz et al., (2009). Also, Abd El-Hamid et al., (2013) 
\&Yassin, (2013) reported that the girls of study sample had regular menstruation with normal interval and their menstrual flow for 5 days. More than half of studied sample had moderate amount of the menstrual bleeding and change pads daily from 3-4 pads /day. This result agrees with Awed et al .,(2013)\&Samir et al .,(2012) who reported that fifty eight percent of studied sample experienced moderate amount of menstrual loss in the 6 months preceding the study and change pads 3 to 5 times /day depending on the day of menses. Three quarters of participants suffer pain. The present study findings were consistent with $\boldsymbol{A} \boldsymbol{b} \boldsymbol{d}$ El-Hamid et al., (2013) who reported that the most common discomforts reported by sample(backache). Also, Khairani et al., (2014) found backache and joint pain is common discomforts. This disagrees with Naeimi,( 2015 ) who reported that the most common symptoms were mood symptom (emotional).The current study demonstrated a highly statistically significant difference between both groups regarding caffeinated beverages intake and severity of PMS through the follow up cycles. Severity of PMS decreased consecutively from month to month and the number of study group students with mild PMS increased while the number with moderate and severe PMS decreased. Also a highly statistically significant difference between study and control samples regarding PMS duration during the three follow up cycles.. PMS duration decreased from month to month in study group meanwhile the percentage was not affected in control group. Bekhatro .(2010). Regarding to interference of PMS with daily activities the interference significantly decreased through follow up cycles due to decreased intake of caffeinated beverages. This result agrees with Eshra et al., (2010) \&Bakhshani et al., (2009). In relation to use lifestyle methods ,the study demonstrated that use of lifestyle methods to overcome PMS discomfort significantly decreased during follow up cycles. This result is in accordance with Chayachinda et al., (2012)who reported that the need to use natural methods decrease after decreasing caffeine intake due to decrease PMS severity. There fore a positive correlation between the reduction of caffeinated beverages intake and decrease in PMS severity at all follow up cycles $\quad(p<0.001)$.the current study indicates a strongly positive link between the reduction of caffeinated beverages intake and decreased severity of PMS and duration.

\section{Conclusion}

Based on the findings of the current study, it was concluded that: -

Caffeine consumption was strongly positively linked to both the severity and duration of PMS. Caffeine consumption decreased intake in the week preceding the menstruation decreased the severity of PMS and duration.

\section{Recommendation}

Counseling adolescent females to reduce caffeine consumption from diet especially the week preceding menstruation and encourage young females to use menstrual diary monthly. In addition, establishing education program for all female students for increasing their knowledge about PMS.

\section{Recommendations for further researches}

-Counseling for women at different age groups about healthy habit regarding premenstrual syndrome management.

\section{References}

AbdElhamidM.,Elmoghazy D.,Moustafa M and Emam E (2013): Knowledge

Akram M.,Akhtar N.,AsifH.,Shah P.,Saeed T.,Mahmood A and Malik N.(2011):Treatment of premenstrual 
syndrome, Journal of Medicinal Plants Research;5(26):pp.6122-6127.

Asmare D., Gezahegn N., Zegeye $\mathrm{M}$ and Meseret G(2015):Prevalence of premenstrual syndrome and associated factors among Debrebirhan Town, North Showa, Amhara Region, Ethiopia,AmericanJournal of Psychiatry and Neuroscience ; 3(1): 8-14.

Awed H., Elsaidey $\mathrm{T}$ And Amro $\mathrm{T}(2013)$ :The use of fresh ginger herbsas a home remedy to relieve primary dysmenorrhea, Journal of Research in Nursing and Midwifery;2(8) pp104:113.

Bakhshani N., Mousavi, M And Khodabandeh G (2009):Factor affecting severity of premenstrual syndromes among iranian female university students, Journal of pakistan Medicine ;59(4), pp205-220.

Barclift S (2010): Premenstrual syndromee ,U.S. Department of Health and Human Services, Office on Women's Health, available at https:// www.Womens

Bayan A., Haifa A., Khalid K., AbdulRazzakandMudhaffarI(2012):"Premenstr ual symptoms in dysmenorrheal college students: prevalence and

Bekhatro A.,Eshra D and Kassem A(2010): Effect of caffeinated beverages on premenstrual syndrome among nursing student at Menofia University, Master thesis, Faculty of Nursing , Menofia University, pp 87:97.

Biggs W\&Demuth R (2011) :premenstrual syndrome and premenstrual dysphoricdisorder, American Family Physician journal ;84(8):918-924.

Brink D (2010): Essentials of statistics, Brink D. (ed.), ventus publishing APS: Frederiksberg, Denmark. $2^{\text {nd }}$ ed:1-103.
Brohi Z., Haider G., Zehra N., \&Amna A. (2011): Frequency and impact of premenstrual syndrome on quality of life, Pakistan Journal of Medical Sciences, 27(2), 396-400.

Chayachinda C., Rattanachaiyanont M., Phattharayuttawat S., \&Kooptiwoot

Diaz A., Laufer M R., and Breech, L L(2009): "Menstruation in girls and adolescents: using the menstrual cycle as a vital sign",Pediatrics journal;118(5):4550 .

Dickerson L P., Pamelaj M and Melissa H H (2003):Premenstrual syndrome,

Eshra D.,Kassem I and Rashed A (2012):Effect of Caffeine Beverages intake On Premenstrual Syndrome, Available at elmagla.egy2010@yahoo.com, Accessed22/5/2016,4:20 P.M .

Falls S. R (2013): The Relationship between Caffeine Consumption Patterns and health. gov/.../ fact-sheet-premenstrual-syndrome, Acc

International Food Information Council Foundation, (2015): Available at American Association of Nurse Practitioners/ www.food insight .org,

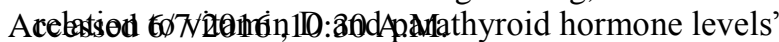

JenabiE(2013), The effect of ginger for relieving of primary dysmenorrhea. J. Pak. Med. Assoc. 63 (1):110-119.

Jiang W, Wu Y and Jiang X (2014):Coffee and caffeine intake and breast cancer risk: An updated dose-response meta-analysis of 37 published studies, Gynecological Oncology journal ;129(3):620-629.

Khairani O., SitiM ., Leelavathi M(2014): "Premenstrual symptoms and remedies practiced by Malaysian women attending A rural primary care",Clinic,ObstetricsandGynecology J ;1 (1) : 1-5. 
Meier, B. (2013): Available at http :// www. nytimes.com ,Accessed on 10/7/2016, 11:30 P.M

Moos R (1968):The development of the menstrual distress questionnaire, Journal of Psychosomatic Medicine ;5, pp 853860.

Naeimi N (2015): The Prevalence and Symptoms of Premenstrual Syndrome under Examination,Journal of Biosciences and Medicines; 3(50): 1-8.

NavdeepKaur, R (2010):A descriptive study to assess the premenstrual syndrome and coping behavior among nursing students, Chandigarh, Nursing and Midwifery Research Journal;5( 1):pp200-213.

Pinkerton J., Pabia G and Taylor M(2010): Menstrual cycle related exacerbation of disease ,National institute of health J;202(3)pp221-231.

Samir N ., Abd el fattah $\mathrm{H}$ And Sayed $\mathrm{E}(2012)$ : The correlation between body mass index and menstrual profile among nursing students of Ain Sham

YassinSh(2012):Herbal remedy used by rural adolescent girls with menstrual 